\title{
Thermal Constant of an Experimental Population of Muscina stabulans (Fallén 1817) (Diptera:Muscidae) in the Laboratory
}

\author{
Luciene Maura Mascarini/ + , Ângelo Pires do Prado*
}

\author{
Departamento de Parasitologia, Instituto de Biociências, Unesp, Rubião Junior s/nº, 18618-000 Botucatu, SP, Brasil \\ *Departamento de Parasitologia, Instituto de Biologia, Unicamp, Campinas, SP, Brasil
}

A study was conducted to investigate the thermal constant in an experimental population of Muscina stabulans (Fallén 1817). A natural population was obtained from a livestock and their $F_{1}$ generations were maintained at four constant temperatures $\left(16^{\circ} \mathrm{C}, 20^{\circ} \mathrm{C}, 26^{\circ} \mathrm{C}\right.$ and $\left.31^{\circ} \mathrm{C}\right)$. The thermal constant was calculated by the hyperbole method using the base temperature, $t b=4.4^{\circ} \mathrm{C}$ and the thermal constant $K=35.3 \mathrm{GD}$. Ricker's geometric regression, considering $t b=7.8^{\circ} \mathrm{C}$ and $K=28.9 \mathrm{GD}$ was also calculated.

Key words: Muscina stabulans - thermal constant - constant temperature

Muscina stabulans (Fallén 1817) (Diptera: Muscidae) a common eusinanthropic fly in farms and orchards, may be associated with human dwellings (Smith 1986). In addition, it can play a role in the control of some Diptera species because of its predatory habits on their larvae (Legner \& Dietrich 1989). The growth pattern and development of insects are influenced by temperature and can be measured under laboratory conditions. It is possible to estimate the number of generations per year and the potential ability of population increase of at a specific temperature by measuring developmental period, mortality and oviposition pattern under constant temperature conditions (Howe 1967). The thermal requirements of an insect can be appraised by the thermal constant (K), expressed in degree-days (Haddad \& Parra 1984). This method has been utilized for many years in forecasting the occurrence of infestations in agriculture and the thermal constant can be used as indicators of the distribution and abundance of insect populations. The objective of this study was to establish a thermal constant for a population of M. stabulans.

Experimental populations of $M$. stabulans were obtained from livestock farm Capuavinha (26 $57^{\circ} \mathrm{S}, 47^{\circ} 19^{\prime} \mathrm{W}$ ), town of Monte-Mor, SP, Brazil. These flies were transferred to cages $(30 \mathrm{~cm} \times 15 \mathrm{~cm} \times 15 \mathrm{~cm})$, where they were fed yeast suggar and water and maintened at $27 \pm 30^{\circ} \mathrm{C}$. Two thousand eggs were collected and dividided into 40 pots $(9.5 \mathrm{~cm} \times 7.5 \mathrm{~cm})$ with 50 eggs/pots and 10 pots (replicates) at each temperature: $16^{\circ} \mathrm{C}, 20^{\circ} \mathrm{C}, 26^{\circ} \mathrm{C}$ and $31^{\circ} \mathrm{C}$, tainning $200 \mathrm{~g}$ of fermented of Labina-Purina mouse ration. To these pots, a further $300 \mathrm{~g}$ of mouse ration was added and the larvae allowed to grow until pupation. $\mathrm{Pu}$ -

Finnancial support: Capes

${ }^{+}$Corresponding author. Fax: +55-14-6821.3744. E-mail: luciene@ibb.unesp.br

Received 9 March 2001

Accepted 5 November 2001 pae were removed and transferred to other cages, where they hatched. The total development time was recorded. The basic development temperature to calculate the thermal constant was determined by the hyperbole method (Bean 1961), using the total development times from the four constant temperature groups. Thermal constant was obtained from the equation $\mathrm{K}=\mathrm{D}(\mathrm{T}-\mathrm{Tb})$, where $\mathrm{K}=$ constant thermal, $\mathrm{D}=$ development time (hours), $\mathrm{T}=$ temperature in which the insect grew and $\mathrm{Tb}=$ basic temperature of the insect, obtained from the Healthy linear regression program (1986) and from Ricker's geometric average (1986) regression program (Krebs 1989).

The Table shows the total development time from larval to adult stage. Average larval development times decreased with increasing temperature. This was inversely proportional to increase in temperature, except at $31^{\circ} \mathrm{C}$ when development time was longer than at $26^{\circ} \mathrm{C}$. The data obtained at $26^{\circ} \mathrm{C}$ are similar to those obtained by Kobayashi and Mizushina (1937) with 14.06 days of total development time, Vinogradova and Marcenko (1984), 12.9 days, and Krzywinski (1993) who analyzed the thermal constant at $28^{\circ} \mathrm{C}$, obtaining an average of 12.9 to 14 days. The total development time, observed by Lewallén (1952) at $26.7^{\circ} \mathrm{C}$, was longer $(20-25)$ that obtained in our study (12.8 days). Thermal requirements were estimated by determining the thermal constant $\mathrm{K}$ and expressed in degree-days. Fig. 1 shows the regression analysis, which showed $\mathrm{Tb}=4.4^{\circ} \mathrm{C}$ and $\mathrm{K}=35.3 \mathrm{GD}$, and Fig. 2 shows Ricker's regression with $\mathrm{Tb}=7.8^{\circ} \mathrm{C}$ and $\mathrm{K}=28.9 \mathrm{GD}$.

Insect body temperature is probably more important than environmental temperature in influencing behavior (Chapmam 1983). Temperature limits can be established by inactivity and by the destruction of some enzymes (Howe 1967). Lethal temperature limits are metabolically regulated by enzymes. Metabolic pattern is measured by oxygen consumption, and when ambient temperature is close to the maximum limit, metabolism is reduced, probably due to denaturation of enzymes (Chapman 1983). The knowledge of the thermal requirements of insects estimated by basic temperature and thermal constant permits, 


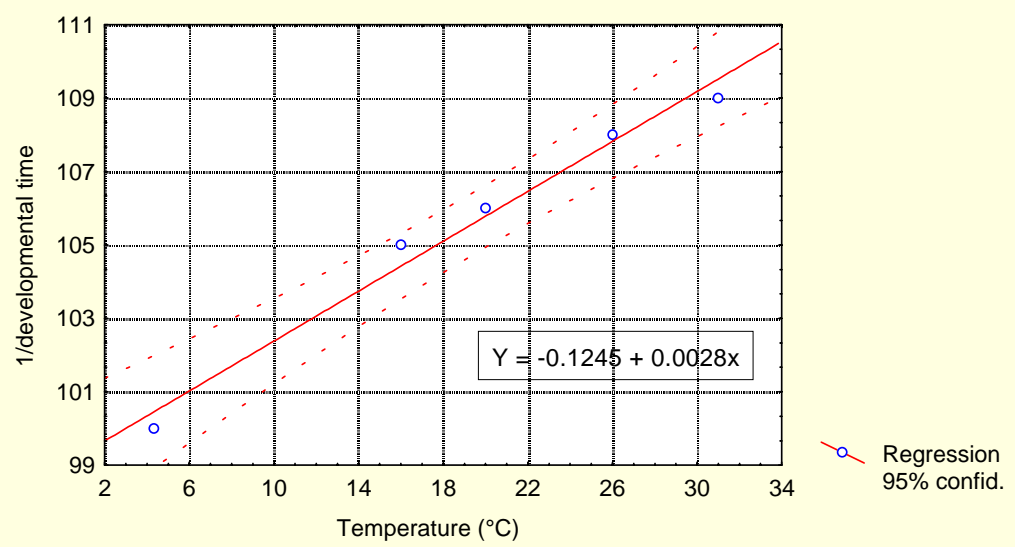

Fig. 1: standard regression analysis of $1 /$ developmental time (temperature) for Muscina stabulans. $\mathrm{Tb}=4.4^{\circ} \mathrm{C} ; \mathrm{K}=35.3 \mathrm{GD}$

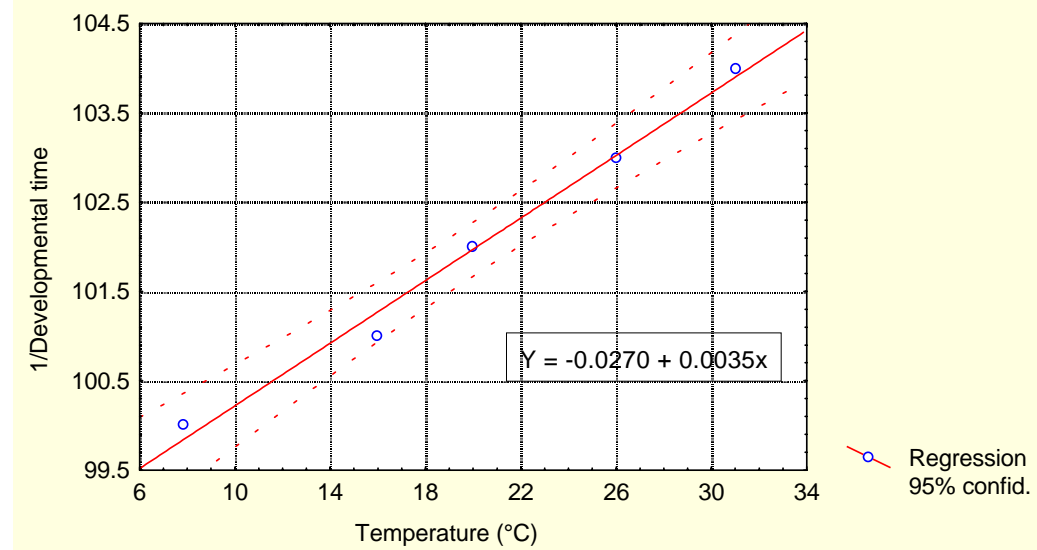

Fig. 2 : Ricker's geometric regression analysis of $1 /$ developmental time (temperature) for Muscina stabulans. $\mathrm{Tb}=7.8^{\circ} \mathrm{C} ; \mathrm{K}=28.9 \mathrm{GD}$

TABLE

Development total time of Muscina stabulans at four constant temperatures (egg-adult)

\begin{tabular}{|c|c|}
\hline Temperature & $\begin{array}{l}\text { Total time of development } \\
\text { (egg-adult) in hours (days) }\end{array}$ \\
\hline $16^{\circ} \mathrm{C}$ & $980 \mathrm{~h}$ (40.8 days) A \\
\hline $20^{\circ} \mathrm{C}$ & $500 \mathrm{~h}$ (20.8 days) $\mathrm{B}$ \\
\hline $26^{\circ} \mathrm{C}$ & 308 h (12.8 days) \\
\hline $31^{\circ} \mathrm{C}$ & 380 h (15.8 days) \\
\hline
\end{tabular}

$\bar{a}: \mathrm{n}=10$. The different letters show statistical significant difference $(p=0.05)$

temporarily, store insects under certain artificial conditions, facilitating study program and field work (AguiarValgorde \& Milward Azevedo 1992). The threshold and thermal constant can also be used as indicators of distribution and abundance of insect populations (Messenger 1959). From these models, temperature occupies a prominent place, because it is a metodologic component that affects insect populations and is easy to predict.

\section{REFERENCES}

Aguiar-Valgorde M, Milward-Azevedo EMV 1992. Determination of the thermal demands of Stomoxys calcitrans (L.) (Diptera:Muscidae), in laboratory conditions. Mem Inst Oswaldo Cruz 87: 11-20.

Bean JL 1961. Predicting emergence of second instar budworm larval from hibernation under field conditions in Minesota. Ann Entomol Soc Am 54: 175-177.

Chapman RF 1983. The Insects: Structure and Function, Hodder \& Stoughton, London, 919 pp.

Hadad ML , Parra JPR 1986. Métodos para Estimar os Limites Térmicos e a Faixa Ótima de Desenvolvimento nas Diferentes Fases do Ciclo Evolutivo dos Insetos, Agricultura e Desenvolvimento, ESALQ, EDUSP, São Paulo, 12 pp.

Healthy Insittute Inc 1986. Healthy User's Guide: Statistics, 6th ed., Cary, North Carolina, 200 pp.

Howe RW 1967. Temperature effect on embrionic development in insects. Ann Ent Rev 12: 15-41.

Kobayashi H, Mizushima H 1937. The relationship between the laboratory temperature and development of flies. $K J$ Med 8: 19-39.

Krebs J 1989. Ecological Methods, Harper \& Row, NY, 654 pp.

Krzywinski J 1993. Development of two Muscina species (Diptera, Muscidae) at constant temperature. Bull Entomol 
Pologne 62: 125-132.

Legner EF, Dietrick EJ 1989. Coexistence of predatory Muscina stabulans and Ophyra aenescens (Diptera: Muscidae) with dipterous prey in poultry manure. Entomophaga 34: 453461.

Lewallen LL 1952. Laboratory studies of the false stable fly. $J$ Econ Entomol 45: 515-517.

Messenger PS 1959. Bioclimatic studies with insects. Ann Rev
Ent 4: 183-206.

Ricker WE 1984. Computation and use of central trend lines. Can J Zool 62: 1897-1905.

Smith KGV 1986. A Manual of Forensic Entomology, British Museum and Cornell University Press, London, 205 pp.

Vinogradova E, Marcenko VM 1984. Ispol'zovanie temperaturnych parametrov razvitija much v sudebnomedicinskoj praktike. Sud-Med Ekspert 1: 16-19. 
